DOI: https://doi.org/10.31392/NZ-npu-142.2019.07

УДКЗ3.032:[373.543]=161.2

Груба Т. Л.

\title{
ПРОБЛЕМА ФОРМУВАННЯ МОВНОЇ ОСОБИСТОСТІ ЯК МІЖДИСЦИПЛІНАРНЕ ПОНЯТТЯ
}

У статті на основі аналізу спеціальної літератури з психології, лінгвістики, лінгводидактики висвітлено основні проблеми, які розробляють дослідники мовної особистості, наведено визначення, виокремлено три аспекти, за якими сформульовано поняття "мовна особистість": антропоцентричний, соџіоцентричний, дисциплінарний. Особливу увагу приділено лінгвістичному й лінгводидактичному напрямам дослідження. У результаті аналізу й синтезу семантичного наповнення поняття "мовна особистість" визначено складність і неоднорідність иього утворення, його динаміку, оскільки мовна особистість перебуває в постійному розвитку під впливом соиіокультурних умов і обставин. Доведено, щу виокремлені науковиями аспекти дослідження мовної особистості взаємопов'язані, бо виходять “за межі" певної наукової галузі, взаємодіють, доповнюють одне одного, стають основою для виділення нових, щэо виникають під впливом різних умов, а також сутнісних характеристик мовної особистості.

У сучасних сочіокультурних реаліях зростає актуальність формування національно свідомої мовної особистості, яка здатна взяти відповідальність за долю рідної мови, за власний мовленнєвий вчинок. Останні дослідження доводять нерозривність між мовною особистістю, мовною ментальністю й національним характером, оскільки в мові кодуються глибинні пласти національної самосвідомості, культурної самобутності народу. Отже, культурна спадкоємність, як спосіб зв'язку між поколіннями даного народу, можлива лише через мову. Всі інші форми спадкоємності (матеріальна культура з усім ї̈ різноманіттям, різновиди художньої творчості) вторинні щодо мови.

Акиентовано на складності структури поняття "мовна особистість" з огляду на його розгляд у широкому контексті (знання мови, володіння мовними засобами, прагнення дослідників виокремити низку окремих компетенцій/компетентностей тощо).

Ключові слова: мовна особистість, антропоцентричний аспект, соиіоцентричний аспект, дисииплінарний аспект.

Проблема фрормування мовної особистості (далі МО) вже тривалий час $€$ предметом багатьох наукових досліджень, що пов'язано передусім зі зміною наукового фокусу з продукту висловлення на його продуцента - людину, яка "виступає суб'єктом породження та сприйняття мовних повідомлень" [4, с. 25]. Перефразовуючи Ф. де Сосюра, І. Голубовська твердить, що інтерес лінгвістів (i не тільки - Т.Г.) наразі перемістився з дослідження правил гри у шахи (структурно-семантичний підхід) на самих гравців (антропоцентричний підхід) $[4$, c. 25]. Окремі напрями дослідження означеного поняття пов'язані 3 соціологією, психологією, лінгвістикою, фрілософрією, педагогікою, лінгводидактикою тощо. Таке поширення терміносполуки можна пояснити ї̈ міждисциплінарністю.

Розроблення проблеми МО в психолінгвістичному аспекті наявне в працях з О. Леонтьєва, Г. Богіна, Л. Засєкіної та інших дослідників; у мовознавстві - $з$ працями Ю. Караулова, Л. Мацько, О. Потебні, О. Селіванової, Л. Струганець 
та ін. у лінгводидактиці - зі студіями Н.Голуб, О.Горошкіної, А. Нікітіної, М. Пентилюк, Т. Симоненко та ін.

Mema cmammi - висвітлити основні проблеми, які розробляють дослідники мовної особистості, оскільки це поняття є міждисциплінарним.

Складно не погодитись 3 думкою про складність і багатовимірність проблеми формування МО, бо вона пронизує всі аспекти вивчення мови й людини, водночас руйнує межі між соціолінгвістикою і психолінгвістикою, між соціальною психологією і вивченням етнічної самосвідомості [3, с. 2; 10, с. 3]. Для нашого дослідження особливий інтерес становлять два напрями дослідження МО - лінгвістичний, що здебільшого реалізується в аспектах психолінгвістики, лінгвостилістики або соціолінгвістики, і лінгводидактичний.

Ю. Караулов подає два визначення МО: "мовна особистість є особистістю, вираженою в мові (текстах) і через мову, є особистістю, реконструйованої в основних своїх рисах на базі мовних засобів" [10, с. 38]; “сукупність (і результат реалізації) здібностей до створення й сприймання мовленнєвих творів (текстів), що різняться: а) ступенем структурно-мовної складності, б) глибиною і точністю відображення дійсності, в) певною цільовою спрямованістю" [10, с. 245]. Обидва визначення людиноцентричні і пов'язані з реалізацією мовленнєвої діяльності.

В. Красних виокремлює чотири різновиди особистості, яка володіє певною мовою: 1) "людина, яка говорить" - особистість, одним із видів діяльності якої $€$ мовленнєва діяльність, що включає як процеси породження, так і сприйняття мовленнєвих повідомлень; 2) мовна особистість - особистість, що реалізує себе у мовленнєвій діяльності на основі сукупності певних знань та уявлень; 3) мовленнєва особистість - особистість, що реалізує себе у комунікації, обираючи та реалізуючи ту або ту стратегію і тактику спілкування, яка обирає та використовує той або інший репертуар засобів (як суто лінгвістичних, так і екстралінгвістичних); 4) комунікативна особистість - конкретний учасник конкретного комунікативного акту, що діє у реальній комунікації [11, с. 50-51].

У Короткому тлумачному словнику лінгвістичних термінів за редакцією С. Єрмоленко МО визначено як “поєднання в особі мовця його мовної компетенції, прагнення до творчого самовираження, вільного, автоматичного здійснення різнобічної мовної діяльності. Мовна особистість свідомо ставиться до своєї мовної практики, несе на собі відбиток суспільно-соціального, територіального середовища, традицій виховання в національній культурі" [21, c. 93].

У Словнику сучасної лінгвістики МО визначено як конкретну особистість, що досконало знає мову, усвідомлено й творчо володіє нею, сприймає мову в контексті національної ментальності й культури як їхнє духовне осердя, уживає мову як невід'ємний елемент самотворення, самопізнання, самоствердження й самовияву, розвитку та вдосконалення власних інтелектуально-розумових та емоційно-рольових, експресивно-почуттєвих можливостей і як найнеобхідніший засіб соціалізації особистості в людському суспільстві [7, с. 345-346]. Доведено, що МО цілком свідомо й відповідально ставиться до власної мовної практики, $є$ виявом соціально-корпоративного, суспільно-культурного, територіальнорегіонального середовища, традицій виховання.

Привернемо увагу й до того, що в наукових працях українських і 
зарубіжних дослідників МО розглядають як носія національної мови та культури (А. Боднар, Й. Вайсгербер, І. Голубовська, Т. Космеда, Е. Стрига та ін.). Так, достатньо переконливими нам видаються твердження, що психоментальний простір МО детермінують такі чинники: 1) залежність мисленнєво-мовленнєвої діяльності суб'єкта комунікації від концептуальної системи світобачення та світосприйняття тієї лінгвокультурної спільноти, до якої належить мовна особистість; 2) комунікативна інтенція, що сформував глобальну змістову настанову мовленнєвої діяльності; 3) комунікативна компетентність - знання носія мови про те, як використовувати мовні ресурси в різних соціокультурних ситуаціях, їх правильність, нормативність, доречність (Т.Радзієвська); 4) соціальна роль адресанта, динамічний аспект, орієнтований на ситуативну варіативність синтаксичних засобів залежно від зміни статусу (ролі) мовця; 5) пресупозитивний та екстралінгвальний характер комунікативної ситуації: соціально-біологічний тип комуніканта, конкретний мотив, ситуація, що спонукають адресанта до мовленнєвої діяльності; 6) стиль спілкування, обраний мовцем для реалізації інтенційних потреб [22, с. 47]. Усі виокремлені чинники уможливлюють думку про змінність і динамічність МО залежно від комунікативного потенціалу ситуації спілкування, набутого соціального, спілкувального й професійного досвіду, рівня сформованих компетентностей. Відтак МО володіє системою національно-культурних цінностей, властивих представникам певного ментального типу, тому "мова становить найбільш загальне культурне надбання. Ніхто не володіє мовою лише завдяки своїй власній мовній особистості; навпаки, це мовне володіння виростає в ній на основі належності до мовної спільноти ..." [2, с. 81].

Вихід дослідження MO в міждисциплінарну площину уможливив виокремлення нових аспектів, і як результат - розширення термінологічного поля дослідження. Вивчення спеціальних джерел дає змогу констатувати, що в наукових працях українських і зарубіжних учених використано поняття "мовленнєва особистість" (В. Красних, О.Кулик та ін.), "комунікативна особистість" (В. Карасик, В.Конецька, Й. Стернін та ін.), "дискурсна (дискурсивна) особистість" (А. Нікітіна, Л. Солощук та ін.), “національно-мовна особистість" (Є.Голобородько, Л. Мамчур та ін.), "елітарна мовна особистість" (Л. Мацько, А. Романченко та ін.).

Зіставному аналізу понять "мовна особистість", "комунікативна особистість" і "дискурсна особистість" присвячено чимало праць науковців. Нашу увагу привернула наукова студія А. Романченко, у якій дослідниця переконливо обґрунтовує кореляцію цих понять. Не вдаючись до дискусії, погодимося зі зробленими нею висновками: "мовну особистість варто кваліфікувати як особистість, яка реалізує себе через вербальну поведінку, утілену за допомогою сукупності лінгвістичних та екстралінгвістичних засобів в усному або письмовому дискурсі. Це уможливлює використання наведеного поняття як гіпернімічного стосовно інших суміжних понять. 3 такого трактування випливає розуміння нами терміна мовна особистість як широкого поняття, до складу якого залучено й комунікативну та дискурсивну особистість, які $€$ частковим виявом особистості" [18, с. 69].

Аналізуючи поняття "мовна особистість" і "мовленнєва особистість", науковці беруть за основу дихотомію "мова - мовлення" і реалізують її, вводячи 
в терміносполуку з поняттям “особистість". Зокрема, О. Кулик, І.Рубан вважають, що мовна особистість - статична; мовленнєва - така, що відображає колізії сучасного мовленнєвого середовища, характеризується більшою динамічністю й залежністю від ситуаційного контексту. На думку дослідників, "мовна особистість - це людина, вбудована в концептуальну систему мови, що дивиться на світ крізь “мовні окуляри” (об”єкт, сфрормований культурою мовлення); мовленнєва особистість людина, здатна говорити, досягати поставленої мети: виразно, доречно, долаючи бар'єри спілкування й уміло використовуючи контексти - лінгвістичний (вербальний), паралінгвістичний (голос, темп, інтонація), екстралінгвістичний (міміка, жести), проксемічний (організація простору, кинестетика), ситуаційний (актуалізація мовної особистості, суб'єктивний вибір мовних засобів у мовному поводженні)" [12, с.87]. Нам видаються правомірними думки дослідників про розгляд мовленнєвої особистості як одного зі способів реалізації МО.

Аналіз і синтез наукових праць засвідчує, що провідною рисою сфрормованості особистості психологи визначають відповідальність. На нашу думку, в сучасних соціокультурних реаліях зростає актуальність фрормування національно свідомої мовної особистості, яка здатна взяти відповідальність за долю рідної мови, за власний мовленнєвий вчинок. Останні дослідження доводять нерозривність між МО, мовною ментальністю й національним характером, оскільки “в мові кодуються глибинні пласти національної самосвідомості, культурної самобутності народу. Отже, культурна спадкоємність, як спосіб зв'язку між поколіннями даного народу, можлива лише через мову. Всі інші форми спадкоємності (матеріальна культура з усім її різноманіттям, різновиди художньої творчості) вторинні щодо мови" [1, с. 59].

Покажемо основні трактування за допомогою таблиці.

Таблиця 1

Трактування мовної особистості в украӥнській лінгводидактиці

\begin{tabular}{|c|c|}
\hline ВИЗНАЧЕННЯ & ABTOP \\
\hline $\begin{array}{l}\text { той носій мови, який не лише володіє сумою лінгвістичних знань (знає } \\
\text { поняття й відповідні правила) чи репродукує мовну діяльність, а й має } \\
\text { навички активної роботи зі словом. Підвалини мовної особистості - } \\
\text { пробудження індивідуальної мовотворчості, таке засвоєння мови, яке } \\
\text { забезпечує вільне самовираження особистості у різних сферах } \\
\text { людського спілкування }\end{array}$ & $\begin{array}{l}\text { С. Срмоленко, } \\
\text { Л. Мацько [9] }\end{array}$ \\
\hline $\begin{array}{l}\text { носій мови, який добре володіє системою лінгвістичних знань (знає } \\
\text { поняття і відвідні правила), репродукує мовну діяльність, має навички } \\
\text { активної роботи зі словом, дбає про мову і сприяє їі розвитку; мовець, } \\
\text { який забезпечує розширення фунцій мови, творення } \\
\text { українськомовного середовища в усіх сферах суспільного життя, } \\
\text { природне бажання повернутися в повсякденному спілкуванні до рідної } \\
\text { мови, до відродження культури, традицій народу, до вироблення } \\
\text { зразків висококультурного інтелектуального спілкування літературною } \\
\text { мовою. }\end{array}$ & $\begin{array}{c}\text { Словник- } \\
\text { довідник } 3 \\
\text { лінгводидактики } \\
\text { [19] }\end{array}$ \\
\hline $\begin{array}{l}\text { високоосвічена людина, котра володіє високим рівнем мовної, } \\
\text { мовленнєвої спроможності, духовності та культури і здатна втілювати } \\
\text { їх в суспільну діяльність для досягнення успішного спілкування та }\end{array}$ & $\begin{array}{c}\text { Л. Мамчур } \\
{[14]}\end{array}$ \\
\hline
\end{tabular}




\begin{tabular}{|l|r|}
\hline \multicolumn{1}{|c|}{ ВИЗНАЧЕННЯ } & АВТОР \\
\hline \hline поставлених життєвих цілей; характеризується такими якостями, як \\
знання лінгвістичних одиниць, необхідних для їх реалізації в усному та \\
писемному мовленні, знання предмета й теми висловлювання, знання \\
поведінки у процесі спілкування та ін.; це комунікативно компетентна \\
особистість, тобто людина, що оперує житєво необхідними знаннями, \\
вміннями й навичками.
\end{tabular}

Наведені визначення лінгводидакти використовують як базові у своїх дослідженнях, доповнюють й уточнюють їх: "важливою особливістю мовної особистості $\epsilon$ її постійний інтелектуальний розвиток, розвиток психічних процесів", її "характеризує духовне багатство та здатність берегти й розвивати традиції національного мовленнєвого етикету" (О.Горошкіна) [5]; "знає особливості українськомовної системи, володіє арсеналом лінгвістичних одиниць і вміло їх", "має вдалий та ефективний соціальний й індивідуальний комунікативний вияв у процесі спілкування" (І. Кучеренко) [13]; “виникає в суспільстві й розвивається, ґрунтуючись на здатності вираження й закріплення соціальних відносин і взаємодій”, “є умовою та продуктом загальної культури людини" (Л. Овсієнко) [17].

Розмаїтість визначень пояснюємо індивідуальністю МО, бо "кожен мовець - це насамперед активний суб'єкт пізнання, наділений індивідуальним і соціальним досвідом, на основі якого він здійснює комунікацію 3 іншими носіями мови, безперервно словесно перетворює доступний для його сприйняття об'єктивний світ" [20, с. 130-131]. На окрему увагу заслуговує думка Л. Мацько про те, що мовна особистість завжди існує в певному часомовному просторі - актуалізованих ідей, концептів і концепцій, понять, значень, смислів і образів, стереотипів мовної поведінки, що сорормувалися і діють у певний час у певній лінгвокультурній спільноті. Науковець переконана, що мовна особистість виражається в мові і мовленні, саме лінгвокультурна спільнота фрормує мовну свідомість як систему поглядів на мову, що відображаються у мовній поведінці. Складниками загального поняття мовної особистості фрілологиня вважає мовну спроможність, мовну свідомість і мовнокомунікативну (дискурсну) діяльність. Мовна спроможність $€$ першоосновою для формування мовної свідомості, а 3 нею і становлення та розвитку мовнокомунікативних компетенцій та компетентності. Система мовної спроможності $€$ генетичною заданістю, їі механізм - динамічним і потужним. Це засвідчують спостереження над мовленнєвим розвитком дошкільнят, учнів, над тим, як зростають i розширюються рівні мовної спроможності у процесі здобування знань, оволодіння сучасними нормами літературної мови - фонетичними, графрічними, лексичними, фразеологічними і синтаксичними, стильовими і стилістичними. На цих етапах відбувається вироблення і закріплення правил мовленнєвої діяльності, формування уявлень, образів, понять, корелятів людського досвіду, знань про світ. Реалізація у розвитку генетично закладеної мовної спроможності фрормує мовну свідомість. Мовна свідомість формує когнітивний (пізнавальний) зміст мовлення [15, с. 144].

Аналіз дефініцій дає змогу говорити про первинність терміносполуки "мовна особистість" і вторинність таких, як "мовленнєва особистість", "комунікативна особистість", “дискурсна особистість". На нашу думку, можна виокремити три 
аспекти, за якими дослідники фрормулюють дефініції: 1) антропоцентричний (маркери - особа, особистість, людина, носій, суб'єкт): науковці привертають увагу до суб'єктності МО і вербальних та невербальних компонентів її реалізації. Як зазначає О. Іванцова, “з усіх варіантів родового компонента визначення МО кращим є "особистість", оскільки нове лінгвістичне термінопозначення не тільки $є$ похідним від терміна, який має давню традицію в психології, фрілософії та соціології, а й дає можливість в максимально короткій і місткій формі позначити сутність міждисциплінарного об'єкта дослідження: це особистість (у всій сукупності її якостей, виявлених суміжними дисциплінами), відображена в мові" [9, с. 27]; 2) соціоцентричний (маркери - національна культура, загальнолюдська культура, полікультурний простір, міжкультурна комунікація та ін.): у більшості визначень акцентовано на "образі носія мови", його національній, ментальній, професійній, віковій та ін. належності. 3 цим пов'язують виокремлення й кореляцію понять "індивідуальна мовна особистість" і "колективна мовна особистість", які нині стають предметом наукових дискусій. 3 цього приводу слушними вважаємо думки А. Загнітка: “активна особистість 3 іï мовним потенціалом істотно впливає на загальномовну стихію колективу. ... навіть особистість як лідер не може одноосібно, без підтримки інших мовних особистостей, кардинально змінити мовне тло колективу, хоча її вплив у загальному колективному вияві може суттєво варіювати $\rightarrow$ модифрікувати $\rightarrow$ трансформувати мовний портрет колективу. ...інколи мовні особистості встановлюють мовні пріоритети, мовні цінності не тільки в мовному колективі, а й загальнонародні $\rightarrow$ загальнонаціональні" [8, с. 24]; 3) дисциплінарний (маркери специфічні для кожної наукової галузі): кожна наукова галузь об'єктом вивчення обирає певний аспект дослідження мовної особистості, наприклад: у лінгводидактиці - володіння мовними й мовленнєвими вміннями, розвиненість мовних здібностей, навички продукувати різножанрові й різностильові висловлення; у лінгвокультурології - особливості національного характеру й мовної ментальності, комунікативній лінгвістиці - особливості комунікативної поведінки МО тощо.

Попри те, що "кожна мовна особистість $€$ унікальною, має власний когнітивний простір", "можливо виділити національну інваріантну частину у її структурі" [16], виокремлені аспекти дослідження МО взаємопов'язані, бо виходять "за межі" певної наукової галузі, взаємодіють, доповнюють одне одного, стають основою для виділення нових сутнісних характеристик МО, засвідчують міждисциплінарний характер дослідження.

Отже, аналіз семантичного наповнення поняття "мовна особистість" уможливив висновок про складність і неоднорідність цього утворення, його динаміку, оскільки мовна особистість перебуває в постійному розвитку під впливом соціокультурних умов і обставин.

Перспективи подальших досліджень вбачаємо у розробленні цілісної моделі формування мовної особистості.

\section{Використана література:}

1. Боднар А. Я., Макаренко Е. М. Взаємодія мовних і ментальних структур у формуванні національної самосвідомості (на прикладі української та російської мов) [Електронний ресурс]. Наук. зап. НаУКМА. Сер. Пед., психол. науки та сои. робота. 2005. Т. 47. С. 56-60. URL : 
http://ekmair.ukma.edu.ua/bitstream/handle/123456789/7755/B odnar_V zayemodiya_movnykh_i_mental 'nykh_struktur.pdf

2. Вайсгербер Й. Л. Родной язык и формирование духа / пер. с нем., вступ. ст. и коммент. О. А. Радченко. Изд. 2-е, испр. и доп. Москва : Едиториал УРСС, 2004. 232 с.

3. Голуб Н. Ознаки компетентності мовної особистості учня. Вісник Прикарпатського університету. 2003. № 1 (48). C. 45-52. URL: http://lib.iitta.gov.ua/3362/

4. Голубовська I. О. Мовна особистість як лінгвокультурний феномен [Електронний ресурс]. Studia Linguistica : зб. наук. праць. Київ : Видав.-поліграф. центр "Київський університет", 2008. Вип. 1. C. 25-33. URL : http://www.philology.kiev.ua//ibrary/zagal/Studia_Linguistica_1/025_033.pdf

5. Горошкіна О.М. Формування мовної особистості випускника профільної школи: лінгводидактичний аспект [Електронний ресурс]. Науковий часопис Національного педагогічного університету імені М.П.Драгоманова. Серія 8. Філологічні науки. (мовознавство $i$ літературознавство) : збірник наукових праць /відп. ред. Л. І. Мацько. Київ : НПУ імені М. П. Драгоманова, 2009. Вип. 3 : до 175-річчя НПУ ім. М. П. Драгоманова. С. 206-211. URL : http://enpuir.npu.edu.ua/handle/123456789/2318

6. Єрмоленко С., Мацько Л. Навчально-виховна концепція вивчення української (державної) мови. Дивослово. 1994. № 7. С. 28-33.

7. Загнітко А. П. Словник сучасної лінгвістики : поняття і терміни : у 4 т. Донецьк : ДонНУ, 2013. T. 2. $350 \mathrm{c}$.

8. Загнітко А., Загнітко Н. Теорія сучасної лінгвоперсонології: рівні й категорії [Електронний pecypc]. STUDIA UKRAINICA POSNANIENSIA, vol.IV. 2016. pp. 23-32. URL : https://pressto.amu.edu.pl/index.php/sup/article/download/5796/5866

9. Иванцова Е. В. О термине "языковая личность": истоки, проблемы, перспективы использования [Електронний ресурс]. Вестник Толского государственного университета. Филология. 2010. № 4 (12). C. 24-32. URL : http://vital.lib.tsu.ru/vital/access/manager/Repository/vtls:000460911

10. Караулов Ю. Н. Русский язык и языковая личность. Изд. 7. Москва : Издательство ЛКИ, 2010. $264 \mathrm{c}$.

11. Красных В. В. "Свій" среди “чужих": миф или реальность? Москва: ИТДГК “Гнозис", 2003. $375 \mathrm{c}$.

12. Кулик О., Рубан I. Мовна й мовленнєва особистість: проблема дефініцій [Електронний ресурс]. Теоретична і дидактична філологія. 2014. Вип. 17. C. 76-89. URL : http://nbuv.gov.ua/UJRN/ Tidf_2014_17_9

13. Кучеренко I. А. Урок - найсприятливіше середовище розвитку мовної особистості учня основної школи [Електронний ресурс]. Науковий часопис НПУ імені М. П. Драгоманова. Серія 8. Філологічні науки (мовознавство $і$ літературознавство) : зб. наукових праць. Вип. 5 / за ред. академіка Л. І. Мацько. Київ: Вид-во НПУ імені М.П. Драгоманова, 2014. С. 326-333. URL : http://enpuir.npu.edu.ua/bitstream/123456789/7124/1/K ucherenko.pdf

14. Мамчур Л. І. Розвиток мовної особистості - пріоритетний напрям сучасної лінгводидактики [Електронний ресурс]. Актуальні проблеми лінгводидактики: реалії та перспективи: матеріали Всеукраїнської науково-практичної конференції / за заг. ред. I. В. Гайдаєнко. Херсон, 2016. С. 105111. URL : https://dspace.udpu.edu.ua/jspui/bitstream/6789/6388/1/M amchur\% 20L .\%20R ozvutok\% 20movnoi\%20osobustosti.pdf

15. Мацько Л. I. Мовна особистість Андрія Малишка як лінгвокультурологічний феномен національного виховання у світлі лінгвофілософії [Електронний ресурс]. Науковий часопис НПУ імені М. П. Драгоманова. Серія 16: Творча особистість учителя: проблеми теорії і практики. 2013. Вип. 20. С. 141-146. URL : http://nbuv.gov.ua/UJRN/N chnpu_016_2013_20_37

16. Нідзельська Ю. М. Співвідношення сутностей цінності, оцінка та мовна особистість у лінгвістиці [Електронний ресурс]. Сучасний стан $і$ перспективи лінгвістичних досліджень та проблем перекладу: Всеукраїнська наукова конференція пам'яті доктора філологічних наук, професора Д.I. Квеселевича. URL : http://eprints.zu.edu.ua/id/eprint/17786

17. Овсієнко Л. Формування мовної особистості студента-філолога на засадах компетентнісного підходу [Електронний ресурс]. URL: http://ephsheir.phdpu.edu.ua:8081/xmlui/bitstream/handle/ 8989898989/187/Формування мовної особистості студента-філолога на засадах компетентнісного підходу.pdf? sequence $=1 \&$ isA llowed=

18. Романченко А. П. Мовна, комунікативна, дискурсивна особистість: проблема кореляції понять [Електронний ресурс]. Науковий вісник Міжнародного гуманітарного університету. Серія: Філологія. 2016. Вип. 25(1). С. 68-70. URL: http://nbuv.gov.ua/UJ RN/Nvmgu_filol_2016_25(1)_21 
19. Словник-довідник з української лінгводидактики : навчальний посібник / кол. авторів за ред. М. Пентилюк. Київ : Ленвіт, 2015. 320 с.

20. Струганець Л. Поняття "мовна особистість" в україністиці [Електронний ресурс]. Культура слова. 2012. Вип. 77. С. 127-133. URL : http://dspace.nbuv.gov.ua/bitstream/handle/123456789/110242/22Struhanets.pdf? sequence=1

21. Українська мова: короткий тлумачний словник лінгвістичних термінів / С. Я. Срмоленко, С. П. Бибик, О. Г. Тодор ; за ред. С. Я. Єрмоленко. Київ : Либідь, 2001. 224 с.

22. Шабат-Савка C. Комунікативна інтенція i психоментальний простір мовної особистості [Електронний ресурс]. Мова $i$ культура. 2011. Вип. 14, т. 4. С. 44-50. URL: http://nbuv.gov.ua/UJRN/M ik_2011_14_4_9

\section{References:}

[1] Bodnar, A. Y a., M akarenko, E. M . (2005). V zaiemodiia movnykh i mentalnykh struktur u formuvanni natsionalnoi samosvidomosti (na prykladi ukrainskoi ta rosiiskoi mov) [Elektronnyi resurs]. Nauk. zap. NaUKMA. Ser. Ped., psykhol. nauky ta sots. robota. T.47. S.56-60. URL: http://ekmair.ukma.edu.ua/bitstream/handle/123456789/7755/B odnar_V zayemodiya_movnykh_i_mental nykh_struktur.pdf

[2] Vajsgerber, J. L. (2004). Rodnoj yazyk i formirovanie duha / per. s nem., vstup. st. i komment. O. A. Radchenko. Izd. 2-e, ispr. i dop. M oskva : Editorial URSS, $232 \mathrm{~s}$.

[3] Holub, N. (2003) Oznaky kompetentnosti movnoi osobystosti uchnia. Visnyk Prykarpatskoho universytetu. № 1 (48). S. 45-52. URL: http://lib.iitta.gov.ua/3362/

[4] Holubovska, I. O. (2008). M ovna osobystist yak linhvokulturnyi fenomen [Elektronnyi resurs]. Studia Linguistica : zb. nauk. prats. K yiv : Vydav.-polihraf. tsentr "K yivskyi universytet", Vyp. 1. S. 25-33. URL : http://www.philology.kiev.ua/library/zagal/Studia_Linguistica_1/025_033.pdf

[5] Horoshkina, O. M. (2009). Formuvannia movnoi osobystosti vypüsknyka profilnoi shkoly: linhvodydaktychnyi aspekt [Elektronnyi resurs]. Naukovyi chasopys Natsionalnoho pedahohichnoho universytetu imeni M.P.Drahomanova. Seriia 8. Filolohichni nauky. (movoznavstvo i literaturoznavstvo): zbirnyk naukovykh prats / vidp. red. L.I. Matsko. Kyiv: NPU imeni M.P.Drahomanova, Vyp. 3: do 175-richchia NPU im. M.P.Drahomanova. S. 206-211. URL : http://enpuir.npu.edu.ua/handle/123456789/2318

[6] lermolenko, S., Matsko, L. (1994). Navchalno-vykhovna kontseptsiia vyvchennia ukrainskoi (derzhavnoi) movy. Dyvoslovo. № 7. S. 28-33.

[7] Zahnitko, A. P. (2013). Slovnyk suchasnoi linhvistyky : poniattia i terminy : u 4 t. Donetsk: DonNU, T. 2. $350 \mathrm{~s}$.

[8] Zahnitko, A., Zahnitko, N. (2016). Teoriia suchasnoi linhvopersonolohii: rivni y katehorii [Elektronnyi resurs]. STUDIA UKRAINICA POSNANIENSIA, vol. IV. pp.23-32. URL: https://pressto.amu.edu.pl/index.php/sup/article/download/5796/5866

[9] Ivancova, E. V. (2010). O termine "yazykovaya lichnost": istoki, problemy, perspektivy ispolzovaniya [Elektronnij resurs]. Vestnik Tomskogo gosudarstvennogo universiteta. Filologiya. № 4 (12). S. 24-32. URL : http://vital.lib.tsu.ru/vital/access/manager/Repository/vtls:000460911

[10] Karaulov, Y u. N. (2010). Russkij yazyk i yazykovaya lichnost. Izd. 7. M oskva: Izdatelstvo L KI, 264 s.

[11] Krasnыkh, V.V. (2003). "Svii" sredy "chuzhykh": myf yly realnost? Moskva : Y TDHK "Hnozys", $375 \mathrm{~s}$.

[12] Kulyk, O., Ruban, I. (2014). M ovna y movlennieva osobystist: problema definitsii [Elektronnyi resurs]. Teoretychna i dydaktychna filolohiia. V yp. 17. S. 76-89. URL : http://nbuv.gov.ua/UJR N/Tidf_2014_17_9

[13] Kucherenko, I. A . (2014). U rok - naispryiatlyvishe seredovyshche rozvytku movnoi osobystosti uchnia osnovnoi shkoly [Elektronnyi resurs]. Naukovyi chasopys NPU imeni M.P. Drahomanova. Seriia 8. Filolohichni nauky (movoznavstvo i literaturoznavstvo) : zb. naukovykh prats. V yp. 5 / za red. akademika L. I. Matsko. Kyiv: Vyd-vo NPU imeni M.P.Drahomanova, S. 326-333. URL : http://enpuir.npu.edu.ua/bitstream/123456789/7124/1/K ucherenko.pdf

[14] M amchur, L. I. (2016). Rozvytok movnoi osobystosti - priorytetnyi napriam suchasnoi linhvodydaktyky [Elektronnyi resurs]. Aktualni problemy linhvodydaktyky: realii ta perspektyvy : materialy V seukrainskoi naukovo-praktychnoi konferentsii / za zah. red. I. V. Haidaienko. Kherson, S. 105-111. URL : https://dspace.udpu.edu.ua/jspui/bitstream/6789/6388/1/M amchur\%20L .\%20R ozvutok\%20movnoi\%200 sobustosti.pdf 
[15] Matsko, L. I. (2013). M ovna osobystist Andriia Malyshka yak linhvokulturolohichnyi fenomen natsionalnoho vykhovannia u svitli linhvofilosofii [Elektronnyi resurs]. Naukovyi chasopys NPU imeni M.P.Drahomanova. Seriia 16: Tvorcha osobystist uchytelia: problemy teorii i praktyky. Vyp. 20. S. 141-146. URL : http://nbuv.gov.ua/UJR N/N chnpu_016_2013_20_37

[16] Nidzelska, Yu. M. Spivvidnoshennia sutnostei tsinnosti, otsinka ta movna osobystist u linhvistytsi [Elektronnyi resurs]. Suchasnyi stan i perspektyvy linhvistychnykh doslidzhen ta problem perekladu : V seukrainska naukova konferentsiia pamiati doktora filol ohichnykh nauk, profesora D. I. K veselevycha. URL : http://eprints.zu.edu.ua/id/eprint/17786

[17] Ovsiienko, L. Formuvannia movnoi osobystosti studenta-filoloha na zasadakh kompetentnisnoho pidkhodu [Elektronnyi resurs]. URL: http://ephsheir.phdpu.edu.ua:8081/xmlui/bitstream/handle/ 8989898989/187/Formuvannia movnoi osobystosti studenta-filoloha na zasadakh kompetentnisnoho pidkhodu.pdf?sequence $=1 \&$ isA llowed=

[18] Romanchenko, A . P. (2016). M ovna, komunikatyvna, dyskursyvna osobystist: problema koreliatsii poniat [Elektronnyi resurs]. Naukovyi visnyk Mizhnarodnoho humanitarnoho univer sytetu. Seriia : Filolohiia. Vyp. 25(1). S. 68-70. URL: http://nbuv.gov.ua/UJRN/N vmgu_filol_2016_25(1)_21

[19] Slovnyk-dovidnyk z ukrainskoi linhvodydaktyky: navchalnyi posibnyk / kol. avtoriv za red. M. Pentyliuk. K yiv : L envit, 2015. 320 s.

[20] Struhanets, L. (2012). Poniattia "movna osobystist" v ukrainistytsi [Elektronnyi resurs]. Kultura slova. Vyp. 77. S. 127-133. URL: http://dspace.nbuv.gov.ua/bitstream/handle/123456789/110242/22Struhanets. pdf? sequence=1

[21] Ukrainska mova: korotkyi tlumachnyi slovnyk linhvistychnykh terminiv / S. Ya.Y ermolenko, S. P. B ybyk, O. H. Todor; za red. S. Y a. Y ermolenko. K yiv : Lybid, 2001. $224 \mathrm{~s}$.

[22] Shabat-Savka, S. (2011). K omunikatyvna intentsiia i psykhomental nyi prostir movnoi osobystosti [Elektronnyi resurs]. M ova i kultura. Vyp. 14, t. 4. S. 44-50. URL: http://nbuv.gov.ua/UJ RN/M ik_2011_14_4_9

ГРУБА Т. Л. Проблема формирования языковой личности какмежедсциплинарного понятия.

В статье на основе анализа спещиальной литературы по психологии, лингвистики, лингводидактики освещены основные проблемы, которые разрабатывают исследователи языковой личности, приведень определения, выделены три аспекта, по которым сформулировано понятие "языковая личность": антропоцентрический, сочиочентрический, дисииплинарный. Особое внимание уделено лингвистическому и лингводидактичному направлениям исследования. В результате анализа и синтеза семантического наполнения понятия "языковая личность" определено сложность и неоднородность этого образования, его динамику, поскольку языковая личность находится в постоянном развитии под влиянием соииокультурных условий и обстоятельств. Доказано, что выделены учеными аспекты исследования языковой личности взаимосвязаны, потому что выходят "за предель" определенной научной области, взаимодействуют, дополняют друг друга, становятся основой для выделения новых, возникающих под влиянием различных условий, а также сущностных характеристик языковой личности.

В современных социокультурных реалиях возрастает актуальность формирования национально сознательной языковой личности, которая способна взять ответственность за судьбу родного языка, за свой речевой поступок. Последние исследования доказывают неразрывность между языковой личностью, языковой ментальностью и начиональным характером, поскольку в языке кодируются глубинные пласты национального самосознания, культурной самобытности народа.

Итак, культурная преемственность, как способ связи между поколениями данного народа, возможна только через язык. Все другие формы преемственности (материальная культура со всем ее многообразием, разновидности художественного творчества) вторичны относительно языка.

Сделан акиент на сложности структуры понятия "языковая личность", учитывая его рассмотрение в широком контексте (знание языка, владение языковыми средствами, стремление исследователей выделить ряд отдельных компетенций / компетентностей и т.n.).

Ключевые слова: языковая личность, антропоцентрический аспект, сочиочентрический аспект, дисциилинарный аспект. 
GRUBA T. L. The problem of forming a linguistic personality as an interdisciplinary concept.

Based on the analysis of special literature on psychology, linguistics, linguodidactics, this article presents the main problems that are developed by researchers of the linguistic personality, the "linguistic personality" definition is given, three aspects are described: anthropocentric, sociocentric, disciplinary. Special attention is paid to linguistic and linguodidactic research. As a result of the analysis and synthesis of the semantic content of "linguistic personality", the complexity and heterogeneity of this formation and its dynamics are determined, since the linguistic personality is in constant development under the influence of socio-cultural conditions and circumstances. It is proved that the aspects of the linguistic personality distinguished by scholars are interrelated, because they go beyond the limits of a certain scientific field, interact, complement each other, become the basis for new ones and emerge under the influence of different conditions, as well as the essential characteristics of the linguistic personality.

In modern sociocultural realities, the relevance of the formation of a nationally conscious linguistic personality, which is able to take responsibility for the fate of the native language, for your speech act, is growing. Recent studies prove the inextricability between the linguistic personality, linguistic mentality and national character, since deep layers of national self-consciousness and the cultural identity of the people are encoded in the language. So, cultural continuity, as a way of communication between the generations of a given people, is possible only through language. All other forms of continuity (material culture with all its diversity, varieties of artistic creation) are secondary to language.

It focuses on the complexity of the "linguistic personality" concept in its broad context (language knowledge, language skills, the desire of researchers to distinguish a number of individual competencies, etc.).

Keywords: linguistic per sonality, anthropocentric aspect, sociocentric aspect, disciplinary aspect.

DOI: https://doi.org/10.31392/NZ-npu-142.2019.08

УДК 373.5.07:336.2

Дарманська I. М.

\section{МЕТОДИ ТА ПРИЙОМИ ФОРМУВАННЯ УПРАВЛІНСЬКОЇ КОМПЕТЕНТНОСТІ МАЙБУТНІХ КЕРІВНИКІВ ЗАКЛАДІВ ЗАГАЛЬНОЇ СЕРЕДНЬОЇ ОСВІТИ}

У статті проаналізовано зміст практичних методів $i$ прийомів, які доиільно використовувати під час підготовки слухачів другого (магістерського) рівня вищої освіти зі спеиіальності 073 "Менеджмент". Визначено оптимальні методи та прийоми, застосування яких вплине на сформованість управлінської компетентності майбутніх керівників закладів загальної середньої освіти. Описано складові управлінської компетентності, а також практичні методи та прийоми, щзо підсилюють їх сформованість: етична (метод лекції, емоційного стимулювання, проблемної ситуації, бесіди); комунікативна (лекиї, навчальної дискусї, практики через дію, ігрові); здоров'язберігаюча (лекиії, проблемно-пошукові, аналітичні); саморозвитку та самоосвіти (лекції, самостійна робота, пояснення, дослідницькі, частково-пошукові); продуктивної діяльності (проблемні лекиії, аналітичні, діагностики); конфліктологічна (лекиії, тренінги, дискусійні, моделювання); психологічна (лекції, пояснювально-мотивуючі, конструювання (моделювання)); загальногалузева (лекції, аналітикопошуковий, моделювання); економічна (лекиії, наочно-демонстраційні, взаємодії); правова (лекиії, проблемні, пояснювально-демонстраційні); предметно-методична (лекиії, самостійні 